\title{
Surgical excision of polymorphous adenocarcinoma in the left maxilla with mucocutaneous flap reconstruction
}

\author{
Exérese de adenocarcinoma polimorfo em maxila esquerda \\ com reconstrução a base de retalho mucocutâneo
}

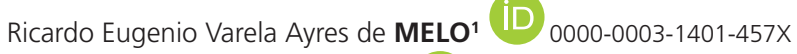 \\ Marcela Côrte Real FERNANDES ${ }^{1}$ iD 0000-0002-4160-9985 \\ Rodrigo Henrique Mello Varela Ayres de MELO² iD 0000-0003-4076-5035 \\ Milena Mello Varela Ayres de Melo PINHEIRO' ${ }^{1}$ iD 0000-0002-5956-1553 \\ Victor Leonardo Mello Varela Ayres de MELO3 ${ }^{3}$ iD 0000-0003-3758-6060 \\ Camilla Siqueira de AGUIAR $^{1}$ (iD) 0000-0001-7376-8393
}

\begin{abstract}
Low-grade polymorphous adenocarcinoma is a malignant neoplasm of salivary glands with uncommon occurrence in the head and neck region, almost exclusively affecting minor salivary glands. While this condition has typical clinical pathological signs, it commonly presents low biological damage potential. The lesions occur more frequently among elderly females between the sixth and eighth decades of life, with a higher prevalence for the hard palate, soft palate and, most regularly, the upper lip and jugal mucosa. The clinical and histological differential diagnosis of this condition is between pleomorphic adenoma and adenoid cystic carcinoma. The most indicated surgical treatment is extensive surgical excision, eventually including resection of the underlying bone. Although infrequent, there may be metastasis for regional lymph nodes. Radical dissection of the neck is not indicated unless there is clinical evidence of cervical metastasis. The present study reports the case of surgical excision of polymorphous adenocarcinoma in the left maxillary tuberosity region. A 63-year-old white male patient sought the Maxillofacial Surgery and Traumatology Service at the Federal University of Pernambuco Clinics Hospital, complaining of a tumor-like lesion in his left maxilla, which gradually increased in volume. The patient further reported a history of surgery ten years before for removal of a tooth in the same region, upper left arch. Given the extent and complexity of the lesion, the surgical treatment in this case consisted of hemimaxillectomy.
\end{abstract}

Indexing terms: Adenocarcinoma, Malignant neoplasm, Salivary gland.

\section{RESUMO}

O adenocarcinoma polimorfo de baixo grau é uma neoplasia maligna das glândulas salivares incomum em região de cabeça e pescoço, ocorre quase exclusivamente em glândulas salivares menores. Entretanto essa patologia apresenta sinais clínico patológicos próprios

\footnotetext{
$\checkmark \nabla v$

1 Universidade Federal de Pernambuco, Ambulatório de Cirurgia e Traumatologia Buco Maxilo Facial. Av. Prof. Moraes Rego, 1235, Cidade Universitária, 50670-901, Recife, PE, Brasil. Correspondência para / Correspondence to: REVA MELO. E-mail: <revamelo@yahoo.com>.

2 Prefeitura de Dionísio Cerqueira, Hospital Nossa Senhora das Graças. Dionísio Cerqueira, RS, Brasil.

3 Universidade Maurício de Nassau, Curso de Odontologia. Recife, PE, Brasil.

$\boldsymbol{\nabla} \boldsymbol{\nabla} \boldsymbol{\nabla}$

How to cite this article

Melo REVA, Fernandes MCR, Melo RHMVA, PINHEIRO MMVAM, Melo VLMVA, Aguiar CS. Surgical excision of polymorphous adenocarcinoma in the left maxilla with mucocutaneous flap reconstruction. RGO, Rev Gaúch Odontol. 2019;67: e2019002. http://dx.doi.org/10.1590/1981-8 6372019000023567
} 
e baixo potencial biológico. A lesão ocorre com maior frequência em indivíduos idosos do gênero feminino, entre a sexta e oitava década de vida, com maior prevalência para as regiões do palato duro, palato mole, sendo o lábio superior e a mucosa jugal as outras localizações mais comuns. O diagnóstico diferencial tanto clínico quanto histológico é feito com o adenoma pleomórfico e o carcinoma adenoide cístico. O tratamento cirúrgico mais indicado é a excisão cirúrgica ampla, incluindo algumas vezes a ressecção do osso subjacente. Podem ocorrer metástases para os linfonodos regionais, porém são incomuns. A dissecção radical do pescoço não está indicada a menos que haja uma evidência clínica de metástase cervical. O presente estudo objetiva relatar um caso clínico de exérese de adenocarcinoma polimorfo em região de tuberosidade maxilar esquerda. Paciente do gênero masculino, com 63 anos de idade, leucoderma, procurou o Serviço de Cirurgia e Traumatologia Buco Maxilo Facial do Hospital das Clínicas da Universidade Federal de Pernambuco, relatando que aproximadamente 10 anos, havia realizado uma exodontia na arcada superior esquerda e a partir desse procedimento cirúrgico, surgiu uma tumoração a nível de maxilar esquerdo, que foi aumentando de volume gradativamente. Diante da extensão e complexidade da lesão se fez necessário realizar a hemimaxilectomia.

Termos de indexação: Adenocarcinoma, Neoplasia maligna, Glândula salivar.

\section{INTRODUCTION}

Polymorphous adenocarcinoma was first described almost simultaneously by two groups of independent investigators: first, in 1983, by Freedman and Lumerman, who named the lesion as lobular carcinoma in analogy to the tumor that occurs in the mammary gland. Later, in 1984, Evans and Batsakis suggested the name lowgrade polymorphous adenocarcinoma, and it was only in 1990 that this entity was recognized as a distinct salivary gland neoplasm by the World Health Organization. Before its identification, this tumor was morphologically categorized as pleomorphic adenoma, a non-specific form of adenocarcinoma, or it was occasionally diagnosed as adenoid cystic carcinoma [1,2]. Low-grade polymorphous adenocarcinoma is a malignant epithelial tumor characterized by cytologic uniformity, morphological diversity, infiltrative growth pattern and low metastatic potential $[1,3,4]$.

This condition has been reported as the second most frequent malignant salivary gland neoplasm, behind only of mucoepidermoid carcinoma. Polymorphous adenocarcinoma accounts for approximately $17.3 \%$ to $26.4 \%$ of all malignant neoplasms of the minor salivary glands $[2,4]$ and is more frequent among female elderlies between the 6th and 8th decades of life [5-7].

Clinically, the lesion may present in the oral cavity as follows: hard to palpation; enlargement of the region; asymptomatic nodule; slow growth; ulceration of the lining mucosa; and locally infiltrative. Occasionally, bleeding and discomfort are reported [1,8]. The most frequently affected sites are the hard palate, soft palate and, especially, the upper lip and jugal mucosa $[3,9,10,11]$. The clinical and histological differential diagnosis of this condition is between pleomorphic adenoma and adenoid cystic carcinoma $[4,10]$.
Low-grade polymorphous adenocarcinoma is clinically characterized as a painless nodule with a diameter ranging from 1 to 4 centimeters, which may be ulcerated in some cases. In approximately $10 \%$ of patients, local lymph nodes are found to be metastatic at the time of diagnosis. In microscopic analysis, low-grade polymorphous adenocarcinoma shows infiltrative cell bundles, absence of a capsule with general lobular morphology and diverse histological patterns, being thus defined as with pseudouniform shape. The tumor cells have spherical and/or polygonal shape and their nuclei can be spherical, fusiform or ovoid with cytoplasm of varied staining. In addition, the cells may have different growth patterns, namely: solid, cribiform, tubular, trabecular, fascicular and papillary form, which justifies the denomination as polymorphous. Peripheral cells generally have infiltrative appearance by invading the underlying tissue in the form of rows. Perineural invasion is common - $30 \%$ of the cases, and this feature makes it difficult to differentiate polymorphous adenocarcinoma from cystic adenoid carcinoma [4]. In some cases, there might be an extension of the tumor towards the underlying bone of the palate or the mandible as well as towards the skeletal musculature [8].

The treatment of choice for low-grade polymorphous adenocarcinoma described in the medical literature is extensive surgical excision with margins, commonly including resection of the underlying bone, with the possibility of combination with radiotherapy. Although infrequent, there may be metastasis for regional lymph nodes. Radical dissection of the neck is not indicated unless there is clinical evidence of cervical metastasis. Cases of recurrence and metastasis are considered rare in the literature $[2,11]$. 


\section{CASE REPORT}

A 63-year-old white male patient sought the Maxillofacial Surgery and Traumatology Service at the Federal University of Pernambuco Clinics Hospital, complaining of a tumor-like lesion in his left maxilla.

During the anamnesis, the patient reported a history of surgery ten years before for removal of a tooth in the upper left arch. He complained that a painless tumorlike lesion developed in his left maxilla, which gradually progressed over time.

At the extra-oral clinical examination, the patient presented a slight increase in volume. The intra-oral clinical examination showed the presence of upper and lower total dentures, an increase in volume in the left maxillary tuberosity region and a lesion of nodular features with fibrous and smooth consistency, fixed, sessile, normochromic, with oval shape, defined edges, and painless symptomatology (figure 1).

Radiographic imaging by panoramic radiography revealed a lesion with mixed radiographic density projected in the left maxillary tuberosity region.

The information provided by conventional radiographic examinations is limited, thus requiring complementary examinations to enable a better diagnosis and surgical planning. In view of that, computed tomography (CT) scans were obtained and used for 3D image reconstruction. An axial tomographic view indicated

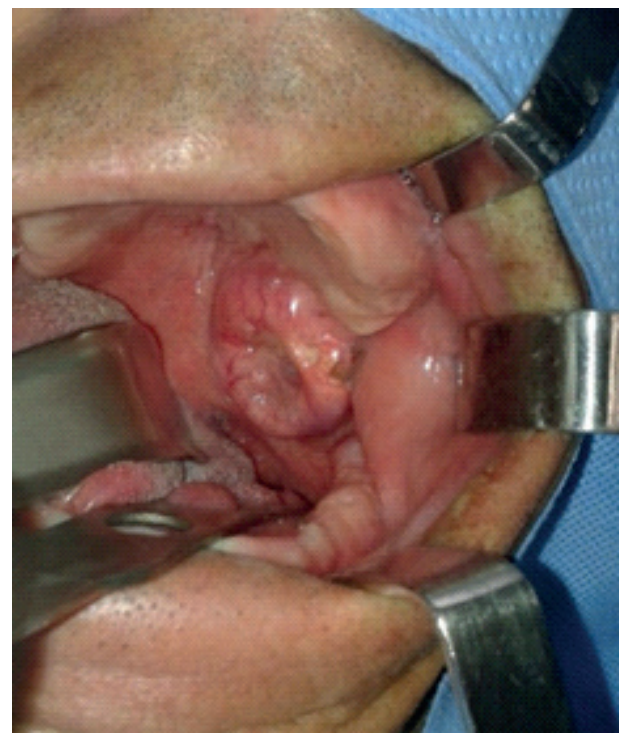

Figure 1. Initial aspect of the lesion affecting the palate, left maxillary tuberosity, tonsillar pillar, jugal mucosa and left retromolar region. the presence of a heterogeneous lesion with osteolysis: alteration in the cortical / trabecular bone and reabsorption of the left palatine bone, with regular contour and defined edges. The following radiographic topography was evidenced: lesion projected into the alveolar process located from the premolar region up to the left maxillary tuberosity region, extending towards the left maxillary zygomatic suture (figure $2 \mathrm{~A}$ and $\mathrm{B}$ ).

The patient was submitted to a surgical procedure under general anesthesia. Initially, an incision was made from the upper labial frenulum region to the left maxillary tuberosity region, followed by a mucoperiosteal flap detachment and resection of the tumor, which encompassed the buccal vestibule, tuberosity, tonsillar pillar and the left retromolar region (figure $3 \mathrm{~A}$ and $\mathrm{B}$ ). Demarcation of segmental osteotomy of the upper left canine, infraorbital region and maxillary tuberosity was performed all the way to the pterygoid process of the sphenoid bone, followed by osteotomy and left hemimaxillectomy with safety margins (figure 3C). Surgery continued with clamping, cauterization of bleeding vessels and curettage of the maxillary sinus. During surgery, a drain was placed through a nasal counter-opening in the left maxillary sinus using a \#14 Nelaton probe. Lastly, the surgery proceeded with mucosal flap reconstruction and interrupted suture with mononylon 5.0 thread.

The patient was prescribed a daily irrigation every 6 hours through a drain using $20 \mathrm{ml}$ syringes and $1 \mathrm{~g}$ sodium cephalothin diluted in $500 \mathrm{ml}$ of $0.9 \% \mathrm{NaCl}$ daily until contents came out clear. During the drainage period, a bloody content was observed in the first days followed by a clear content in the last days, thus enabling the patient's hospital discharge. The following procedures were also prescribed: vital signs monitoring; free diet according to tolerance; $5 \%$ dextrose saline, $1500 \mathrm{~mL}, 21$ drops/minute, continuous delivery; complex B + vitamin C in saline, 1 ampoule in each phase; cephalothin sodium (1g), 1 vial i.v. every 6 hours; dexametazone $(4 \mathrm{mg}), 1$ vial i.v. every 6 hours $(2.5 \mathrm{ml}=10 \mathrm{mg})$; metoclopramide dydrochloride (10mg), 1 ampoule i.v. every 6 hours in case of nausea or vomiting; codeine phosphate $(30 \mathrm{mg})$ associated with paracetamol (acetaminophen) (500mg), 1 tablet by mouth every 8 hours; keep headboard raised to 30o; continuous thermotherapy since the first 24 hours preceded by cryotherapy in the first 24 hours.

The patient remained hospitalized for five days at the Federal University of Pernambuco Clinics Hospital to 


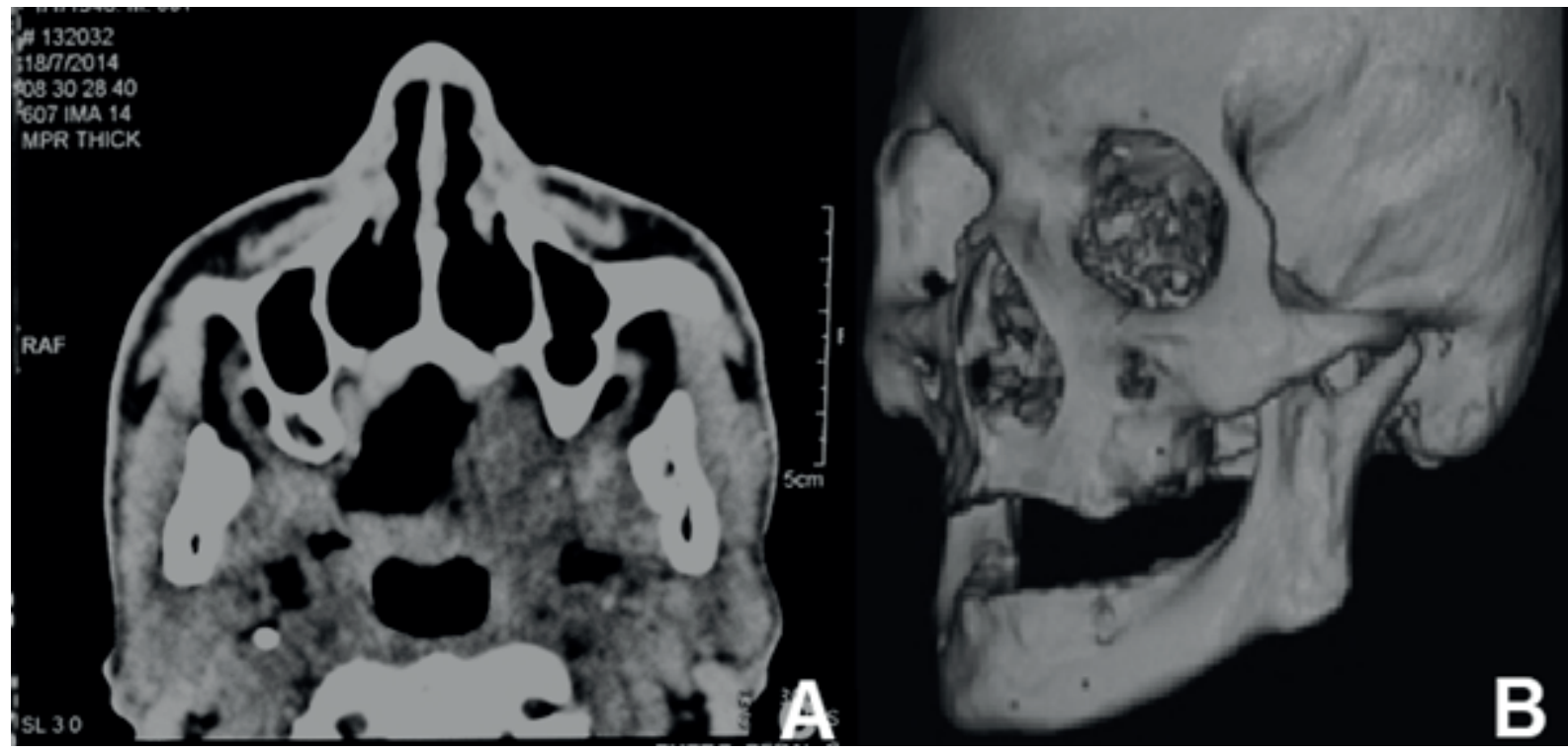

Figure 2. (A) Axial CT scan of the face; (B) CT scan of the face with three-dimensional partial reconstruction in external view, showing a tumor of heterogeneous density on the left side involving the premolar region and the corresponding maxillary tuberosity. Note the partial impairment of the airways.

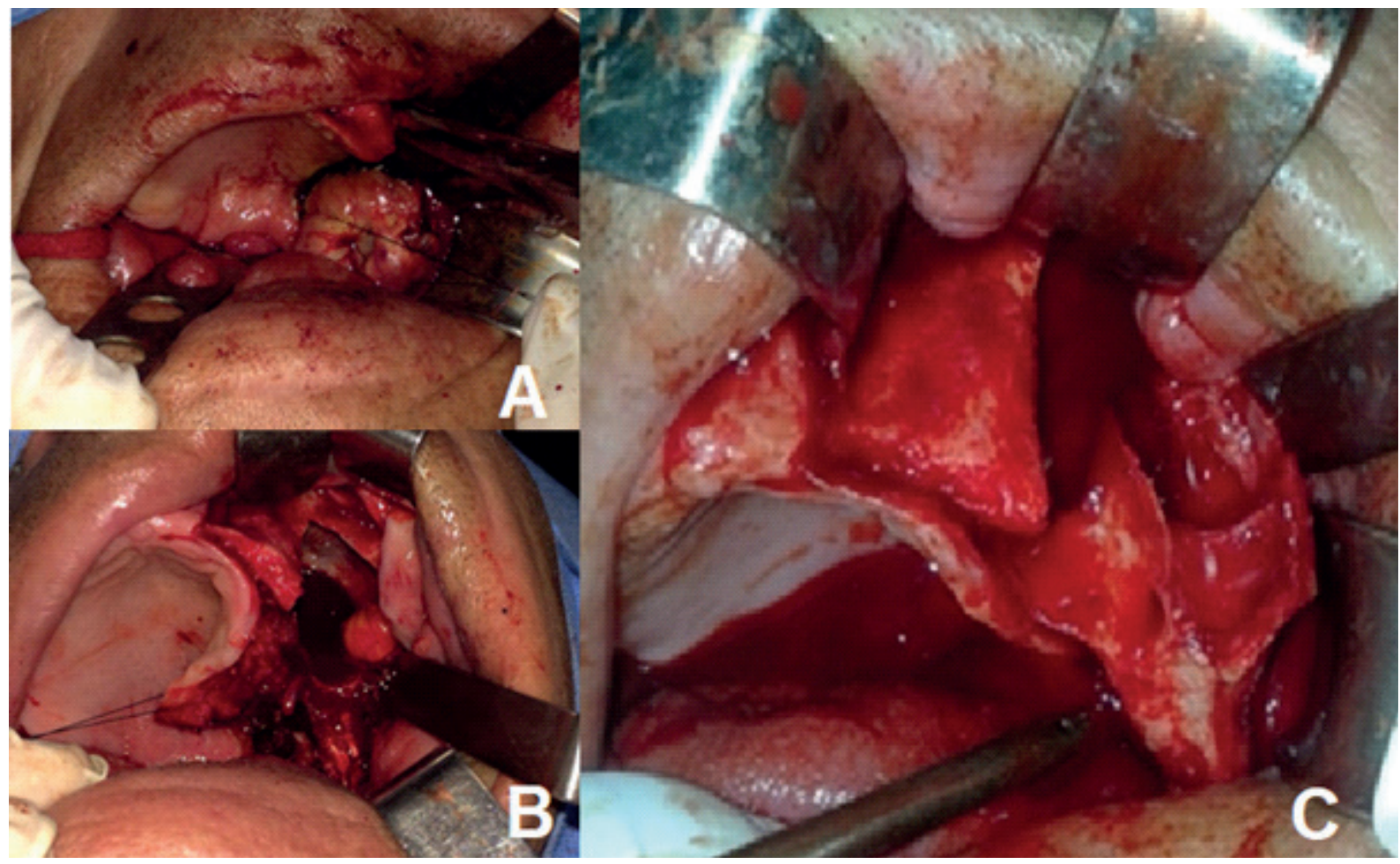

Figure 3. (A and B) Resection of the lesion and (C) left hemimaxillectomy.

receive the care procedures previously mentioned. After hospital discharge, the patient was prescribed ampicillin trihydrate 500mg, 20 tablets every 6 hours for 5 days and paracetamol (acetaminophen) 750mg tablets every 4 hours, in case of pain. The late postoperative period was uneventful, and after 15 days the sutures were removed at the outpatient clinic. The patient was followed up for a period of 24 months and presented complete tissue 
adaptation in the operated region, with good healing and favorable esthetics, with no evidence of relapse (figure 4). The procedure performed in the present case consisted of the most commonly used therapy for malignant lesions, as it completely removed the tumor and restored the aesthetics and function of the oral tissues.

The surgical specimen (figure 5) was sent to the Oral Histopathology Laboratory of the Federal University

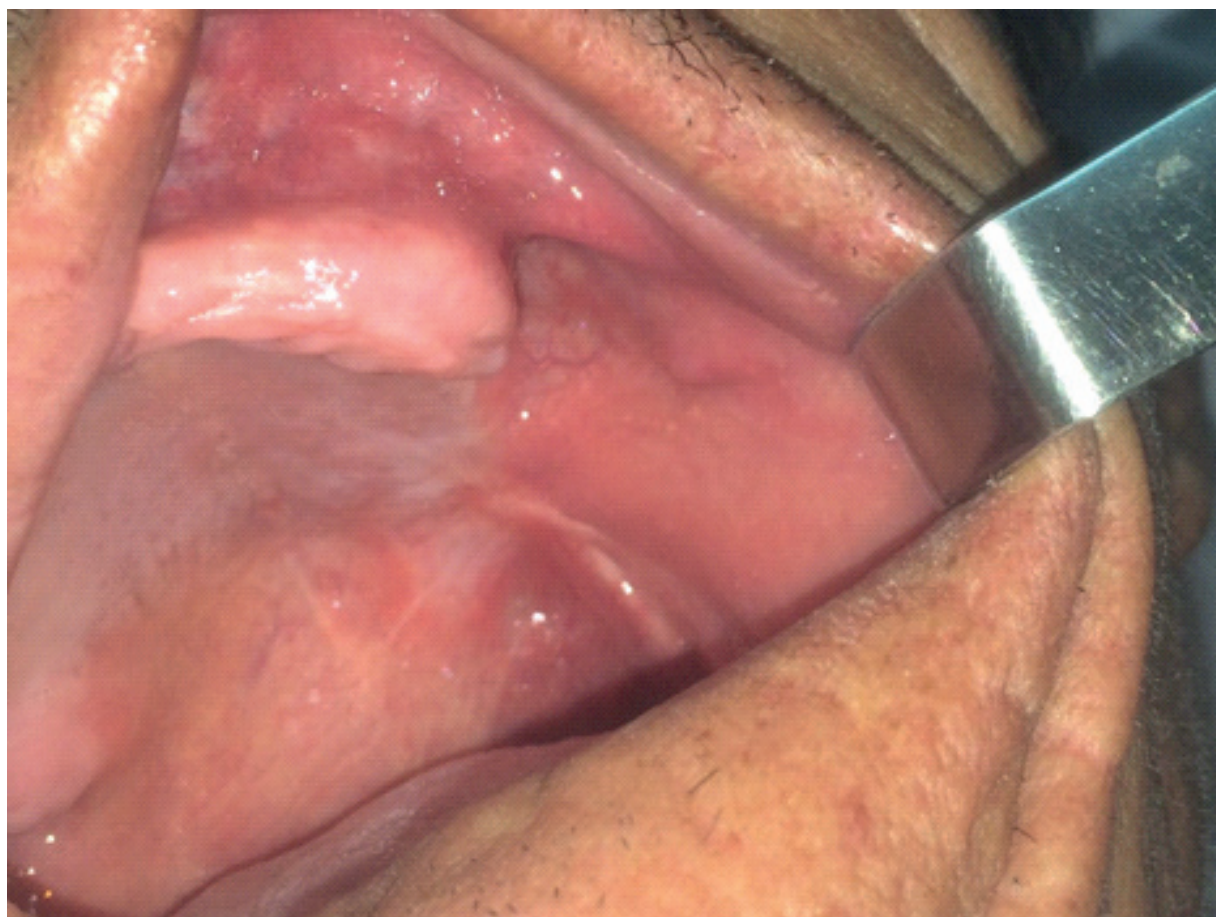

Figure 4. Postoperative follow-up of 24 months.

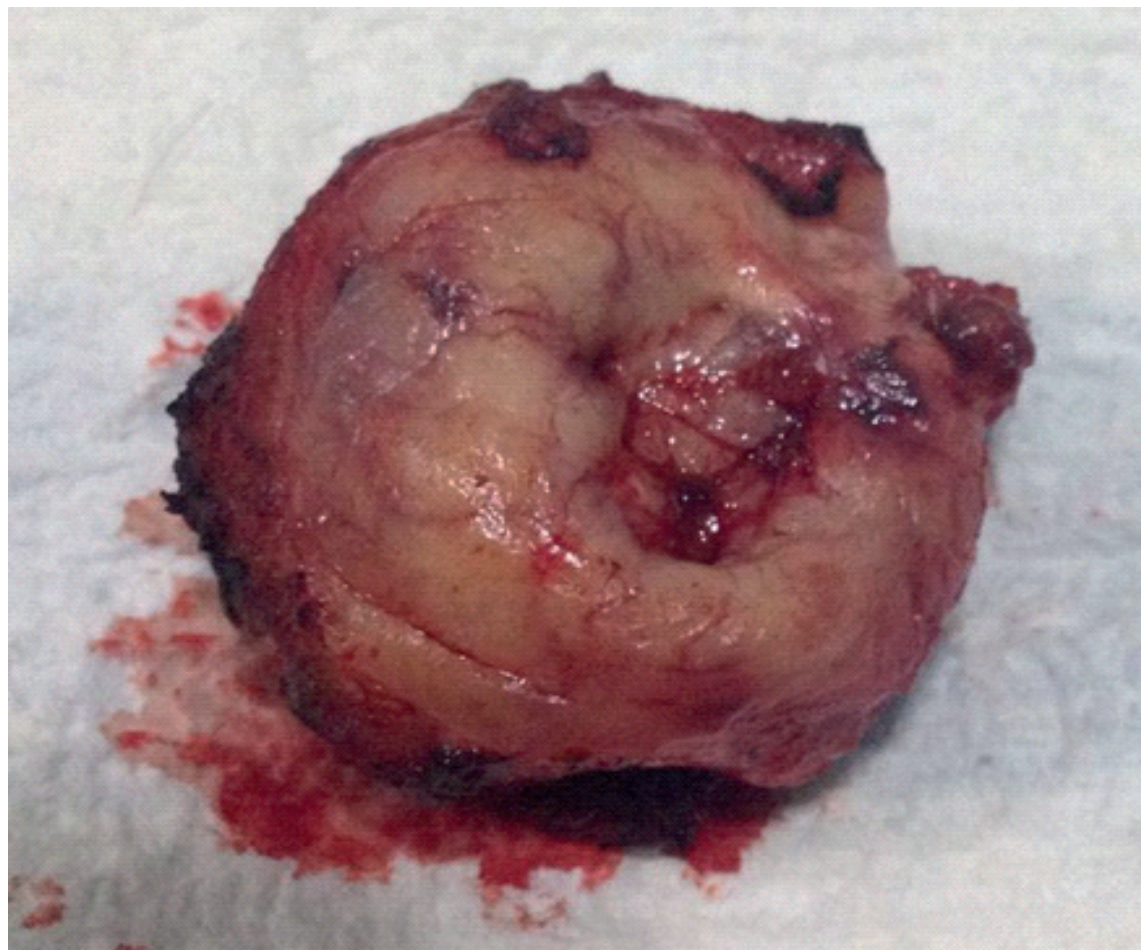

Figure 5. Surgical specimen. 
of Pernambuco, where the free margins were confirmed. Microscopically (figure 6), the lesion presented areas of peripheral infiltration and the presence of tumor cells in the subepithelial region; neoplastic cells with oval nuclei arranged in ducts, with intra-ductal papillary proliferation; neoplastic oncocytic cells; tumor cells with oval nuclei, arranged in ducts and with hyaline stroma, as well as tumor infiltration of adjacent adipose tissue.

By signing an Informed Consent Form, the patient became aware that the healthcare service would use data provided during the interview, as well as those collected during the treatment (photographs, complementary examinations, casts, among others) for didactic and scientific purposes (articles, reviews, abstracts). The publication aims solely to contribute to science; there is no identification of the volunteer, except among the authors; and the confidentiality of their participation was ensured.

\section{DISCUSSION}

The medical literature has reported that tumors of the minor salivary glands are rare neoplasms $[1,3,4,11]$, with low-grade polymorphous adenocarcinoma accounting for a small percentage of these.

According to Neville et al. [9], the sites most frequently affected by polymorphous adenocarcinoma are: hard palate, soft palate, and especially the upper lip and the jugal mucosa. Therefore, it is very important to report new cases of this type of tumor, particularly focusing on diagnosis and clinical management of the condition, since misconceptions in the analysis of minor biopsies are common. Corroborating with the aforementioned authors, we report in this study a new clinical case of this rare malignant salivary gland neoplasm in a male patient and further discuss the main current aspects for a correct diagnosis and clinical management.

The studies by Fife et al. [5] and Shukla et al. [7] pointed out that the palate is the site mostly affected by polymorphous adenocarcinoma, which is in agreement with the present case and with several publications. In addition, although this neoplasm affects almost exclusively minor salivary glands, it can also occur in the lungs, parotid gland, submandibular gland and maxilla. In line with these authors, the present case describes the occurrence of polymorphous adenocarcinoma in the left maxillary region.

Fernandes et al. [2] and Lima et al. [6] reported a higher prevalence of polymorphous adenocarcinoma in females, which is in contrast with the case described herein. The study by Shukla et al. 5 indicated a higher frequency in the age group between the 5th and 8th decades of life, which was confirmed in the present case where the patient was 63 years old at the time of diagnosis.

Menezes et al. [8] reported that low-grade polymorphous adenocarcinoma may appear clinically

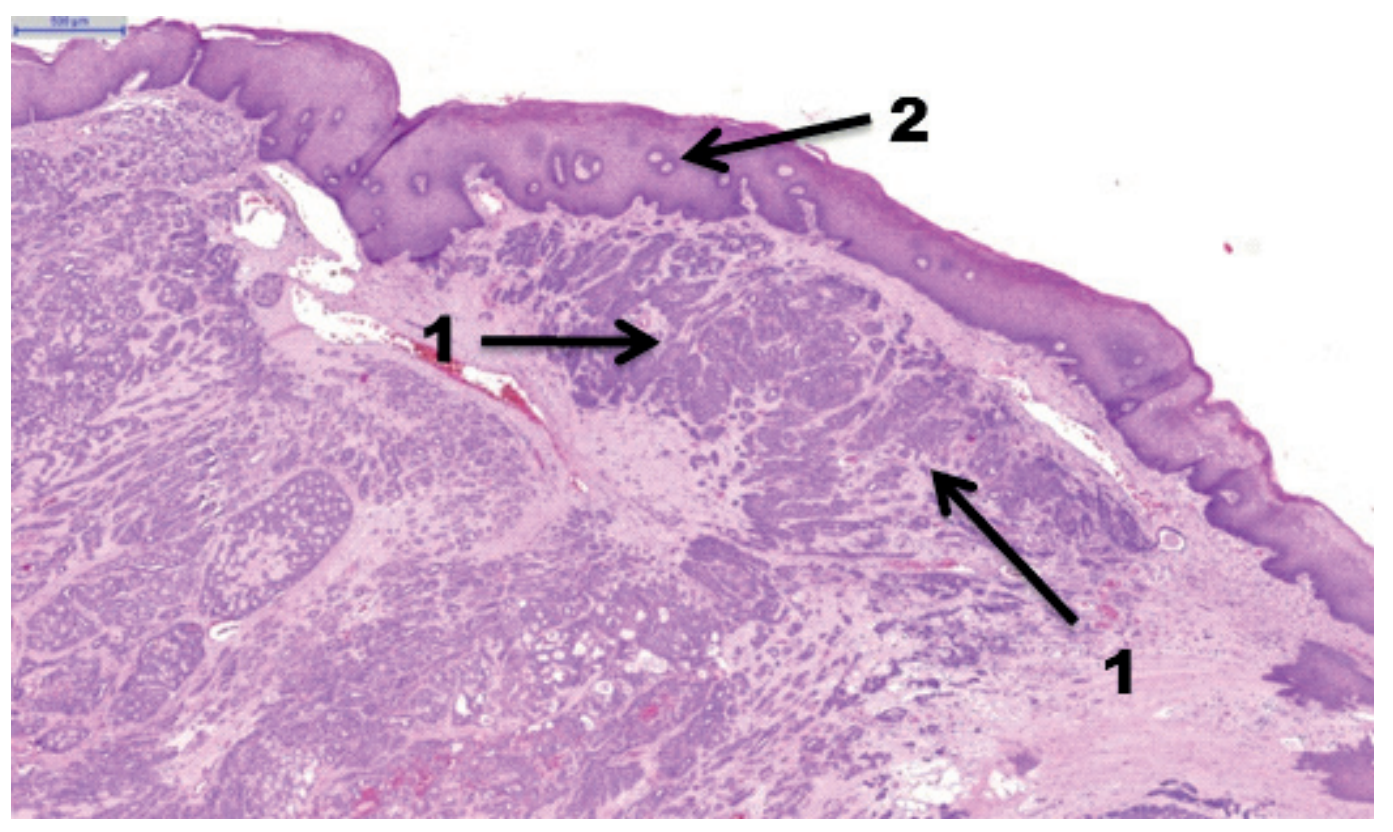

Figure 6. (1) Areas of peripheral infiltration; (2) tumor cells in the subepithelial region. The figure demonstrates the neoplastic infiltration underlying the palatal Malpighian epithelium, revealing the various architectural patterns such as solid, tubular arrangement, cribiform pattern and cellular cords. (40x). 
as a nodular lesion with embossed edges, lining mucosa ulceration, locally infiltrative, with slow growth, asymptomatic and poorly bleeding. These clinical features were also observed in the present case during the anamnesis, leading to the establishment of an initial clinical diagnosis of a benign neoplasm.

According to the studies by Menezes et al. [8], lowgrade polymorphous adenocarcinoma exhibits a cytological "pseudouniformity" with a diversity of histological patterns. Its cells may be spherical and/or polygonal, with spherical, fusiform or ovoid nuclei, and cytoplasm with varied staining. The tumor cells can proliferate in solid, cribiform, tubular, trabecular, fascicular and papillary growth patterns, corroborating with the clinical case presented herein in which the lesion presented areas of peripheral infiltration and the presence of tumor cells in the subepithelial region; neoplastic cells with oval nuclei, arranged in ducts, with intra-ductal papillary proliferation; neoplastic oncocytic cells; tumor cells with oval nuclei, arranged in ducts, and with hyaline stroma, besides presenting tumor infiltration of the adjacent adipose tissue.

The diagnosis of polymorphous adenocarcinoma can become challenging due to the differential diagnosis with other neoplasms, namely: pleomorphic adenoma and cystic adenoid carcinoma, described in the literature by Araújo et al. [1]. This is in agreement with the present case, whose differential diagnostic hypothesis was between pleomorphic adenoma and adenoid cystic carcinoma.

The surgical excision of the lesion is reported by several authors, among them Neville et al. [9], Verma et al. [10] and Lee et al. [12] as the choice of treatment for low-grade polymorphous adenocarcinoma. In the present case, hemimaxillectomy was performed because of the infiltrative potential of the lesion towards other anatomical regions. Fernandes et al. [2] points out that more severe cases may require radiotherapy in combination with the surgical treatment, an option not considered for the present clinical case. The Oncology Service did not recommend radiotherapy because the lesion was removed with safety margins and had not metastasized to other regions, as confirmed by the Oral Histopathology Laboratory of the Federal University of Pernambuco.

\section{CONCLUSION}

Low-grade polymorphous adenocarcinoma is a rare malignant neoplasm that affects the salivary glands whose potential for malignancy, recurrence and metastasis, is relatively low. It is of great importance that the dentist has the appropriate knowledge about this condition, especially because there is a higher prevalence of this neoplasm in the oral cavity, generally manifesting in the hard palate, soft palate, upper lip and jugal mucosa.

The diagnosis of low-grade polymorphous adenocarcinoma becomes complex as it presents clinical and histological features similar to those of pleomorphic adenoma and cystic adenoid carcinoma.

Based on cases described in the medical literature, surgical excision with safety margins is the procedure of choice. In more severe cases, it is recommended to remove the adjacent bone, due to the local infiltrative potential of the lesion. Therefore, in order to detect possible recurrences or, very rarely, metastasis, it is necessary to perform a clinical and radiographic follow-up.

\section{Collaborators}

REVA MELO was responsible for the conceptualization, data curation, formal analysis, funding acquisition, investigation, methodology, project administration, resources, software, supervision, validation, writing-original draft and writing-review \& editing. MCR FERNANDES was responsible for the data curation, Investigation, software and writing-original draft. RHMVA MELO was responsible for the conceptualization, data curation, formal analysis and writing-original draft. MMVAM PINHEIRO is responsible for data curation, software and writing-original draft. VLMVA MELO and CS AGUIAR, academics, were process views.

\section{REFERENCES}

1. de Araujo VC, Passador-Santos F, Turssi C, Soares AB, de Araujo NS. Polymorphous low-grade adenocarcinoma: an analysis of epidemiological studies and hints for pathologists. Diagn Pathol. 2013;8:6. http://dx.doi.org/10.1186/1746-15 96-8-6

2. Fernandes KS, Sedassari BT, Rocha L, Medeiros FB, Pinto Junior $D S$, Ortega $K L$, et al. Adenocarcinoma polimorfo de baixo grau: relato de caso clínico. Sci Invest Dent. 2014;16(1):5-9.

3. Chatura KR. Polymorphous low grade adenocarcinoma. J Oral Maxillofac Pathol. 2015;19(1):77-82. http://dx.doi.org/10.41 03/0973-029X.157206

4. Akhavan A, Binesh F, Nafis MR. Polymorphous low grade adenocarcinoma of submandibular gland. Rep Pract Oncol Radiother. 2015; 2(1): 675. https://doi.org/10.1016/j.ooe.2005. 07.002

5. Fife TA, Smith B, Sullivan CA, Browne JD, Waltonen JD. Polymorphous low-grade adenocarcinoma: a 17 patient case 
series. Am J Otolaryngol. 2013; 34(5): 445-448. http://dx.doi. org/10.1016/j.amjoto.2013.03.012

6. Lima NKV, Santos WHN, Pérez DEC, Castro JFL, Carvalho EJA. Estudo retrospectivo de tumores de glândulas salivares. Odontol Clín-Cient. 2015;14(3): 699-705.

7. Shukla M, Gaud U, Kumar M, Pandey M. Polymorphous lowgrade adenocarcinoma (PLGA) in an 18-year-old male. Indian J Surg. 2013;75(2):153-155. http://dx.doi.org/10.1007/s12 262-012-0804-1

8. Menezes PAF, Macário JA, Franco AVM, Pordeus SS, Almeida WA, Peixoto FB. Adenocarcinoma polimorfo de baixo grau: relato de caso. RvAcBO. 2016;25(2):235-242.

9. Neville B, Damm DD. Patologia oral e maxilofacial. $4^{a}$ ed. Rio de Janeiro: Elsevier; 2017.
10. Verma V, Mendenhall WM, Werning JW. Polymorphous lowgrade adenocarcinoma of the head and neck. Am J Clin Oncol. 2014; 37(6): 624-626. http://dx.doi.org/10.1097/COC. Ob013e31827e5537

11. Wang TC, Yang YT, Tsai MT. Polymorphous Low-Grade Adenocarcinoma: a rare cause of long-term epistaxis. Arch Otolaryngol Rhinol. 2016; 2(1): 27-29.

12. Lee DH, Yoon TM, Lee JK, Lim SC. Polymorphous low-grade adenocarcinoma of the maxillary sinus. J Craniofac Surg. 2013;24(3):e213-4. http://dx.doi.org/10.1097/SCS.0b013e3 $1827 f f 1 a 2$

Received on: 8/4/2018 Final version resubmitted on: 18/6/2018

Approved on: 6/11/2018 